\title{
Author Correction: Lkb1 suppresses amino acid- driven gluconeogenesis in the liver
}

Pierre-Alexandre Just, Sara Charawi, Raphaël G. P. Denis (1), Mathilde Savall, Massiré Traore, Marc Foretz (D), Sultan Bastu, Salimata Magassa, Nadia Senni, Pierre Sohier, Maud Wursmer, Mireille Vasseur-Cognet, Alain Schmitt, Morgane Le Gall, Marjorie Leduc, François Guillonneau (D), Jean-Pascal De Bandt, Patrick Mayeux, Béatrice Romagnolo, Serge Luquet, Pascale Bossard \& Christine Perret (D)

Correction to: Nature Communications https://doi.org/10.1038/s41467-020-19490-6, published online 30 November 2020.

This Article contained an error in the Data Availability statement. Reference to the phosphoproteome data of refed animals, deposited to the PRIDE repository, was accidentally omitted. The data are accessible via accession number PXD019755. This information has now been added to the Data Availability statement for both the PDF and HTML versions of this Article, as well as the Reporting Summary.

Published online: 17 March 2021

\footnotetext{
(c) (i) Open Access This article is licensed under a Creative Commons Attribution 4.0 International License, which permits use, sharing, adaptation, distribution and reproduction in any medium or format, as long as you give appropriate credit to the original author(s) and the source, provide a link to the Creative Commons license, and indicate if changes were made. The images or other third party material in this article are included in the article's Creative Commons license, unless indicated otherwise in a credit line to the material. If material is not included in the article's Creative Commons license and your intended use is not permitted by statutory regulation or exceeds the permitted use, you will need to obtain permission directly from the copyright holder. To view a copy of this license, visit http://creativecommons.org/licenses/by/4.0/.
}

(C) The Author(s) 2021 